\title{
Place of Worship as Capital Space: The Relationship between Masjid Raya Bandung and Shopping Centers
}

\author{
Yuris Fahman Zaidan ${ }^{1^{*}}$, Aquarini Priyatna ${ }^{2}$, R. M. Mulyadi ${ }^{3}$ \\ 1 Universitas Padjadjaran, Indonesia; e-mail: fahmanyuris@gmail.com \\ 2 Universitas Padjadjaran, Indonesia; e-mail: aquarini@unpad.ac.id \\ 3 Universitas Padjadjaran, Indonesia; e-mail: r.m.mulyadi@unpad.ac.id \\ * Correspondence
}

Received: 2020-04-08; Accepted: 2020-12-03; Published: 2020-12-30

\begin{abstract}
The mosque is generally known as a place of worship for Muslims. Besides being seen as a physical and spiritual space, a mosque is also a cultural space. The culture is manifested through the everyday life of people who are connected to the mosque. The economy is part of the everyday life that will connect the mosque with other economic sectors such as shopping centers. This research will show the relationship between the mosque and shopping centers that contribute to the development or production of capital space in the city. Masjid Raya Bandung (MRB) is the focus of research to uncover the formation of capital space and its relationship with shopping centers around the MRB. The method used is observation and in-depth interviews with people visiting the mosque and shopping centers. The theory used to look at this case is the production of space from Henri Lefebvre. The results showed that the mosque was not only seen as a place of worship, but also a capital space. The formation of this capital space can be seen from the relation of MRB with the shopping places around it and the relations of the activities of visitors who presuppose these two spaces: the mosque and the shopping centers. That way, the mosque is used as a means of perpetuating the economic process or consumerism in the surrounding spaces, including in shopping centers.
\end{abstract}

Keywords: Capitalism; Mosque; Production of Space.

Abstrak: Masjid secara umum dikenal sebagai tempat beribadah bagi umat Islam. Selain dilihat sebagai ruang fisik dan spiritual, masjid pun merupakan ruang budaya. Budaya tersebut termanifestasi lewat kehidupan keseharian dari tiap orang yang terkoneksi dengan masjid. Ekonomi merupakan bagian dari kehidupan keseharian tersebut yang akan menghubungkan masjid dengan sektor-sektor ekonomi lainnya seperti pusat perbelanjaan. Penelitian ini akan menunjukkan relasi antara masjid dan pusat pembelanjaan yang berkontribusi pada pembangunan atau produksi ruang kapital di perkotaan. Masjid Raya Bandung (MRB) menjadi fokus penelitian untuk menyingkap pembentukan ruang kapital dan relasinya dengan pusat perbelanjaan yang ada di sekitar MRB. Metode yang dipakai adalah observasi dan wawancara mendalam pada orang-orang yang mengunjungi masjid dan pusat perbelanjaan. Teori yang digunakan untuk melihat kasus ini adalah produksi ruang dari Henri Lefebvre. Hasil penelitian menunjukkan bahwa masjid bukan hanya dilihat sebagai tempat ibadah, tetapi juga menjadi ruang kapital. Pembentukan ruang kapital ini bisa dilihat dari relasi MRB dengan tempat-tempat belanja yang ada di sekelilingnya dan relasi kegiatan para pengunjung yang mengandaikan dua ruang tersebut: masjid dan pusat perbelanjaan. Dengan begitu, masjid dijadikan sebagai sarana pelanggengan proses ekonomi atau konsumerisme di ruangruang sekitarnya termasuk di pusat perbelanjaan.

Kata Kunci: Kapitalisme; Masjid; Produksi Ruang.

\section{Introduction}


In general, the meaning of the mosque is still relatively narrow. In various dictionaries, a mosque is often defined as a place of worship for Muslims. This makes it possible to view the mosque from a different perspective which does not place it solely as a place of worship. This article intends to raise another issue about mosques, namely by using a spatial study. This issue is directed to review the extent to which the role of mosques in contributing or building capital space.

The concept of the mosque was first introduced in Arab, this is inseparable from the presence of Islam which makes mosques an important place for its activities. In Arabic, the mosque is generally interpreted as a place of prostration in all parts of the earth. Masajid (plural form of a mosque in Arabic) is the place where the forehead, palms, knees, and toes rest. So in particular the mosque is a place of prayer as an illustration that someone is prostrate there (Husain ibn Muhammad Al-Raghib AlAsfahani, 2004, p. 251).

Mosque in the study of space certainly does not see it limited to its function as a place of worship. As Henri Lefebvre (1991) said, space is produced through a historical process. History, representation, and the form of reality in space are related to theology, customs, law, ideology, institutions, or socioeconomic structures. The activities of the people who visit the mosque can be seen when they have other interests besides worship. Some talk about economics, politics, or just traveling with their families. Research from Sidi Gazalba shows that a mosque is a multifunctional place. Mosques can be functionalised according to the socio-cultural conditions that are present in the environment (Gazalba, 1994) . In other words, a mosque is the result of the formation of the culture of the people around it.

The diversity of activities in the mosque implies a view that the mosque contains various discourses in addition to the discourse on worship. Discourse is specifically understood as the totality of meaning produced through a series of articulation practices that can represent aspects of reality, whether physical, social, or psychological, and subtly able to negotiate those realities (Laclau \& Moeffe, 1985, p. 107). Meanwhile, the discourse on mosques can be grouped into physical and social classifications. Physical aspects are centered on the building itself in a particular architectural style, such as interior decoration or construction. Meanwhile, the social aspect relates to rituals and social activities in mosques (Khan, 1990, p. 126).

The mosque's discourse on the physical and the social is certainly relevant to the study of space, especially regarding the production of space. According to Lefebvre, the production of space is not only related to physical problems, but space is also a social product (Lefebvre, 1991). Subjects who are active in space have the potential to shape their environment according to what they have practiced (Ryan, 2010, pp. 13-14).

In Lefebvre's magnum opus entitled The Production of Space, in general, an important concept to highlight is his three frameworks regarding the production of space. The three frameworks are spatial practice, representation of space, and space of representations. Everything is related to each other in space (Ghulyan, 2019)

Spatial practice refers to the various practices, activities, or social relations that are present in a space. The spatial practice is seen as the same as a social practice. Spatial representation is a space designed by professionals such as architects, scientists, urbanists, technocrats, or other social engineers (McAlister, 2005). Meanwhile, representation space is a space that is generated because of the dialectical relationship between spatial practice and spatial representation. The representation space contains symbols and images that make a space come alive (lived space). Space becomes something special and is perceived by everyone, be it individuals, groups, or communities who carry out activities in that space (perceived space) (Lefebvre, 1991, p. 37).

In daily practices that appear in space, for Certeau humans always intersect with strategy and tactics. A strategy is a force that regulates certain spatial boundaries, covering a wide area of power, so the strategy is a space where the subject and its power operate. Following Lefebvre regarding spatial practice, the subjects referred to in the strategy according to Certeau are professionals such as urban designers or urban planners who allow the space to be created and functioned properly. Meanwhile, tactics are another force that emerges - from space users - because of pressure or unfavorable 
conditions. Subjects who are positioned in tactics independently can oppose false and restrictive formal forces (Certeau, 2001, pp. 130-131).

The production of space will lead to the mode of production of capitalism which often affects space as a commodity. The space conditioned by capitalism and the production relations in it is known as abstract space (Lefebvre, 1991). In a capitalist society, space is always conditioned in the form of a commodity. In other words, space is in the process of reorganising capital space. However, as Boer said capitalism that operates in an abstract space is still regarded as early capitalism. Meanwhile, after abstract space, Lefebvre named it contradictory space, which is the space produced by late capitalism (Boer, 2015, p. 96).

Mosque in the study of space production thus also discusses mosque as a means of accelerating capital penetration. This is because the production of space that Lefebvre means is the production of space that leads to the capitalist mode of production (Lefebvre, 1991, p. 53). On the other hand, the economic structure also becomes an important part of the mosque as a social aspect (Khan, 1990, p. 126). To see more clearly how mosques are used as a means of facilitating capital penetration, I will choose the Masjid Raya Bandung (MRB) as a case study to be studied. This selection is certainly not random, there are two reasons why I choose MRB. First, MRB is a mosque located in the city center surrounded by shopping centers. This makes it possible for me to see how the mosque is used as a part to reproduce the workforce or consumers who carry out activities in shopping centers. Second, the physical arrangement or public facilities in MRB such as toilets, entrances, places for ablution are arranged in such a way that visitors who shop around MRB can easily access them.

The focus of this research will be directed to position the spatial relation between mosques and shopping centers as a cultural discourse that needs to be analysed. The implication is that this research will also look at how people who attend shopping centers are also supported by the presence of mosques as a means of support so that their economic activities can continue.

Referring to the three concepts of space production according to Lefebvre, this study will analyse the relationship between mosques and shopping centers in building or producing capital space. I will explore how the spatial practices that occur between the two spaces using the three concepts of spatial practice, representation of space, and space of representational. In the part of spatial practice, MRB will be seen as a space that supports various economic activities including those involved around shopping centers in MRB. Furthermore, the concept of representation of space is used to view MRB from the point of view of the MRB designer, in this case, the Bandung City government. In reviewing MRB as a spatial representation, I will explore what the main purpose of developing MRB is. This tracing is of course historical in nature to track changes in socio-cultural conditions from the start of MRB development to the present day. Meanwhile, to see the space of representational, I will see how MRB is perceived space by people who visit MRB, especially those involved in shopping centers.

To produce a deep analysis of daily practices in the mosque space, this study borrows Michel de Certeau's ideas about strategy and tactics. This theory is used to see two contradicting daily practices in space - in this object is MRB.

There are several studies on mosques using the theory of space production. Istiqamah and Herlily's research illustrates how the people who were in the production of the mosque space in Banda Aceh after the Tsunami also represented Islam in every building. This is because the culture of the Acehnese people itself is closely related to Islamic traditions (Istiqamah \& Herlily, 2018). After that, Rahmadi Agus Setiawan's research discussed the production of religiosity carried out by local communities around the Pathok mosque (Setiawan, 2017). Further research from Yulia Eka Putrie and Luluk Maslucha reviewed the mosque and the behavior settings of the people living in it (Putrie \& Maslucha, 2013).

Ashadi's research, et al. examines how the daily practices exist in Luar Batang Mosque, North Jakarta (Ashadi \& Nur'aini, 2017) Mosques seen from a spatial study perspective can also be found in Siswanti's research which discusses the function of the Sendang Dawur mosque as a cultural space. The mosque not only functions as a place of worship but contributes to the acculturation between Islamic and pre-Islamic cultures (Siswanti, 2016). 
Marwati and Sutriani's research also discusses mosques from the perspective of spatial studies (Marwati \& Sutriani, 2019). The article was written by Kong also discusses mosques by looking at the hegemony of ideology and political symbolism that is reflected in Singapore (Kong, 1993). Another similar study discussing mosques from a spatial perspective is an article by Hassan-Udin Khan. The article discusses the concept of mosque design taken from several countries (Khan, 1990). Mateo's (2019) research also discusses mosques and spaces but is more focused on education spaces. Nyhagen's article also discusses mosques from the perspective of spatial and gender studies (Nyhagen, 2019).

Starting from the research that has been done before, there has been no research on how the relationship between mosques and shopping centers in building or producing capital space in MRB. Therefore, this paper is expected to contribute to the discourse of the mosque, especially about the production of space. In particular, this article aims to examine the extent to which mosques are used as cultural spaces for the continuity of capital production.

This study presents the results of research on the relationship between MRB and shopping centers in producing capital space. Two issues will be discussed. First, discussing the spatial relation between MRB and shopping centers, in examining these relations I will look at the history of the formation of the space to the spatial relations that have occurred until now. Second, discussing spatial practices that work or emerge in the spatial relationship between MRB and shopping centers. The spatial practices that will be observed and analyzed focus only on four actors: visitors, traders, workers, and religious communities. Apart from the four actors, the second sub-chapter will discuss the collision of daily practices.

\section{The Relationship Between MRB and Shopping Centers in Producing Capital Space}

This section explains the formation of MRB space from a historical perspective and how the relationship changes with shopping centers. The formation of space from a historical perspective is seen as part of the representation of the space between MRB and today's shopping centers. As Lefebvre wrote, space cannot be separated from its history because space is produced through a historical process (Lefebvre, 1991, p. 46). In analysing the historical formation of capital space, I use historical sources about MRB, these sources are then reconstructed and narrated according to the topics discussed. After analysing the history of the spatial relation between MRB and capital space, I then made direct observations into the field to see how current spatial conditions are in building the relation of capital production.

The current MRB has undergone various spatial changes according to the historical context. These changes produce capital space. The mosque and Bandung squares since colonial times have not functioned as shopping centers. According to Kunto, the functions of MRB include administrative, social, cultural, and defense functions. More shopping centers are located on Jalan Braga which has the highest social standing in Bandung (Kunto, 1986, p. 402).

Shopping centers in the 1800s can also be found around the Bandung square. The first market in Bandung is located in Kampung Ciguriang, behind Kapatihan. The market was first established in 1812. At that time, Ciguriang was the first market close to MRB and Bandung square (Kunto, 1996, p. 38). The distance from MRB to Jalan Ciguriang is about 450 meters. Research has not been found at that time whether there was a strong relationship between MRB and the Ciguriang market in strengthening economic activity in the market. MRB was founded during the reign of R. A. Wiranatakusumah (17941829). MRB was inaugurated on 25 September 1810 along with the inauguration of the pavilion. Another opinion said that MRB was built in 1812 (Istiqamah \& Herlily, 2018). I was unsuccessful in exploring the spatial relationship between MRB and the Ciguriang market at that time because of the very limited research and references I got.

After the Ciguriang market was burned down, the shopping center in the city of Bandung disappeared. Some of the traders started their activities around Bandung square and MRB. MRB and the square at that time did not function as a shopping center. In the morning, MRB and the square tend to be quiet because the community workplaces are still scattered and far from the city center. The loss 
of the Ciguriang market had an impact on traders who then created a new shopping place which is now known as Pasar Baru (Kunto, 1986, p. 408).

The activities of the traders who were spatially adjacent to MRB began in the 1920s. In that year the west of MRB still looks empty and not yet filled with malls or shopping buildings. Beside the road, you can still see big trees and passing vehicles, but it is not as crowded as it is now (see Figure 1). The streets and activities get busy at night, turning into a lively night market. In this market, some traders sell food, such as surabi (Sundanese and Indonesian specialties whose main ingredients are rice flour and wheat) and fried peanuts. Apart from food vendors, the market also functions as a venue for film screenings and ronggeng performances (Javanese traditional dance) (Kunto, 1984, p. 226). At present, there are still food traders around MRB as before, but for ronggeng shows and film screenings are no longer enforced. This proves that space changes also have an impact on cultural changes that take place in that space. Borrowing Ryan's term that the environment will influence the kinds of cultural practices which then these practices will have an impact on the formation of a new physical environment (Ryan, 2010, pp. 13-14).

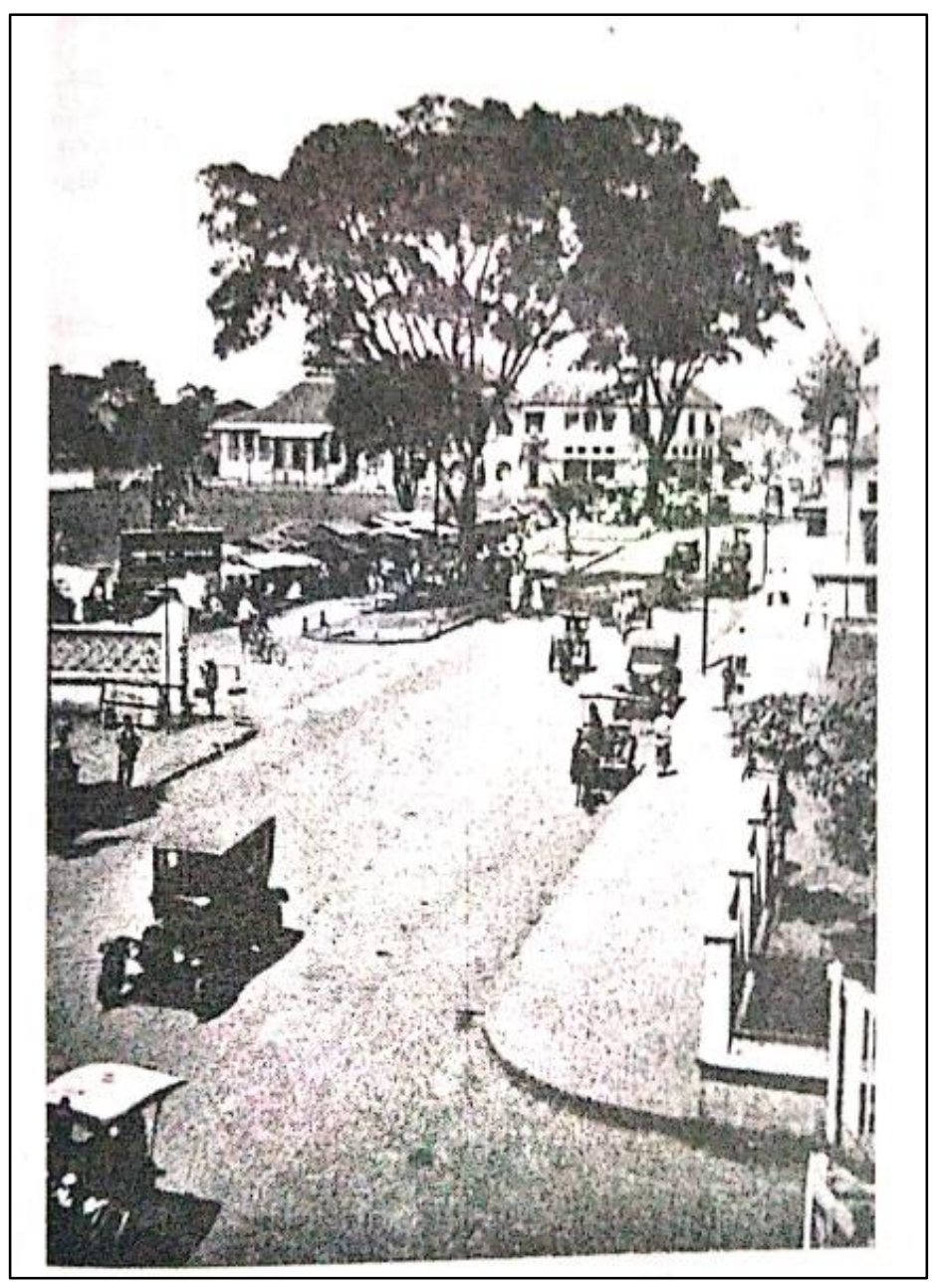

Figure 1 West of MRB in the 1920s

Source: Kunto (1984)

Over time, the people of Bandung began to apply MRB as a space for economic activity, for example in the early 1950s traders gathered in front of MRB. In that year, traders such as coffee, mixed ice, ang bok bread, bajigur, barbers, to horseshoe repairmen gathered in front of MRB (Kunto, 1986, p. 467). This proves that the presence of the mosque at that time was used as a space for the formation of the community's economy (see figure 2). 


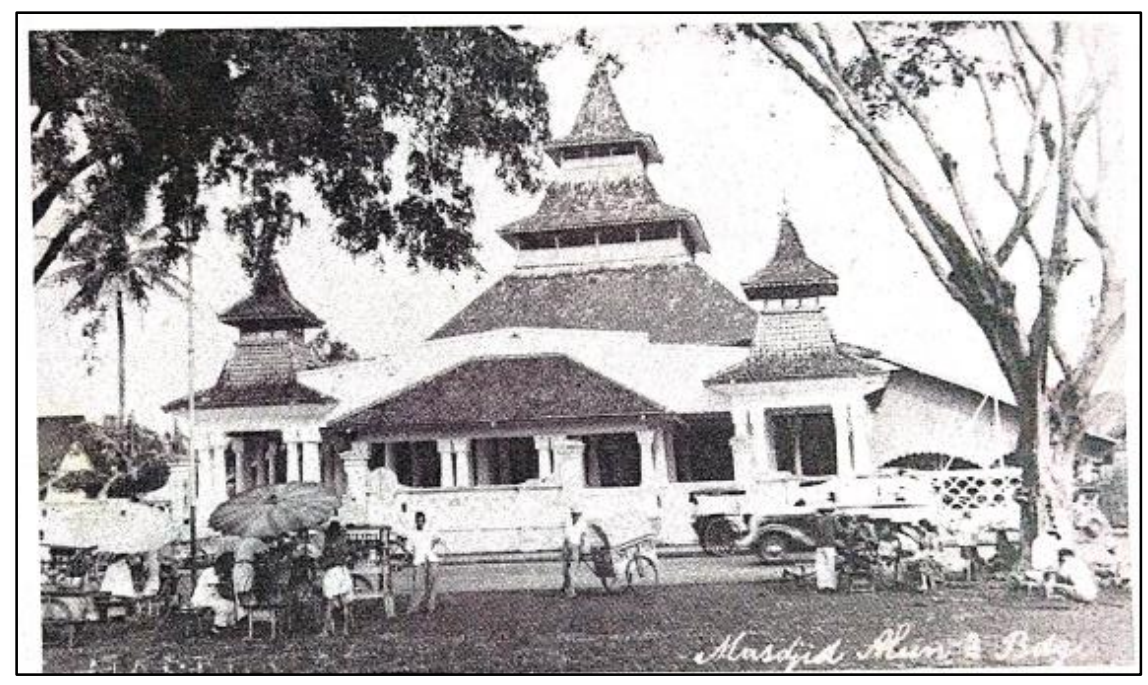

Figure 2 MRB conditions in the 1950s

Source: Kunto, (1986)

When the construction became more massive since the 1970s, the square has turned into an MRB plaza. This change began with the construction of a connecting bridge between MRB and the square. The construction of the bridge was carried out by the Bandung City Government with the aim that residents visiting the square could easily carry out worship (Falah, Yuniadi, \& Andyawardhina, 2019). According to Kunto (1984, p. 219), the existence of a bridge and concrete connecting the mosque and the square have eliminated the meaning of the square as a cultural center of the city and has turned it into a shopping center. Before the square became a plaza, people's activities were centered there. Massive development since the 1970s has slowly changed the spatial relations and daily practices that have worked or surfaced in MRB.

After MRB was expanded, other buildings began to appear, one of which was a shopping center. For example, Mall Parahyangan Plaza, which is located on Jalan Dalem Kaum, was first established in 1982. The expansion of MRB had an impact on economic development in the city center. MRB is a tourist area with the presence of a link between the mosque and the square. This proves that the mosque can be used as a medium for the economic sustainability of the shopping centers around it.

According to Pawitro, in 1987 the shopping center located at Jalan Dalam Kaum was widely known by some people in Bandung. The place is a shopping center for several segments: various clothes, textiles, shoes, bags, and children's toys (Pawitro, 2015). The mosque space, plaza squares, and shopping center spaces are parts that are connected. MRB as a space for the sustainability of shopping centers from a historical perspective has eliminated culture or memories of Bandung. The modernisation of the city by carrying out several renovations to the square and MRB had an impact on the culture or daily practices of the people which are currently no longer seen. Today's daily practices cannot be found anymore, for example in 1925 the people of Bandung often held arrow matches in the square. Some of the participants even came from outside Bandung. The residents gathered to stay in touch while watching the competition (Kunto, 1984). The reforms that have occurred in MRB have made public squares and open spaces narrower. The implication is that the past culture that appeared in the square is lost because now it has become a mosque area.

In the past, the square had its philosophical meaning. The buildings that stand around the square reflect the trias of politics in democratic life. Keraton symbolises the executive, the mosque is interpreted as a legislative where people conduct deliberations, and prison is a physical symbol of the judiciary. Meanwhile, the two banyan trees in front of the mosque symbolise the civil service - who must protect the people (Kunto, 1984, p. 230). This meaning has been lost because space has changed. Automatically, the cultural meanings present in the space also change. Falah's research shows that there is a shift in 
the philosophical meaning of the square which is no longer seen as the boundary between profane and sacred areas (Falah et al., 2019, p. 216).

Meilawati's research on Bandung square shows that there have been several changes in function. First, when the square functions as a holy and sacred area and is part of the pavilion. Second, when Indonesia became independent, the plaza had a function as part of the political, social, and economic sphere. Third, when the square is more positioned as a city park and tourist attractions. Fourth, until the end of the 20th century, the square had been removed and turned into a mosque plaza (Meilawati, 2019, p. 92).

MRB was again expanded in 2000-2003, and even a third of the square was used as land for renovating the mosque, after completion of the renovation, the mosque which was originally named Masjid Agung Bandung was changed to MRB (Falah et al., 2019). The expansion of the MRB building in that year, apart from taking part in the square parkland, also took over a piece of road on the west side of the square (Afriandi, 2003, p. 34). This expansion is seen as a condition for the formation of capital space, one of which affects the worship center around the mosque.

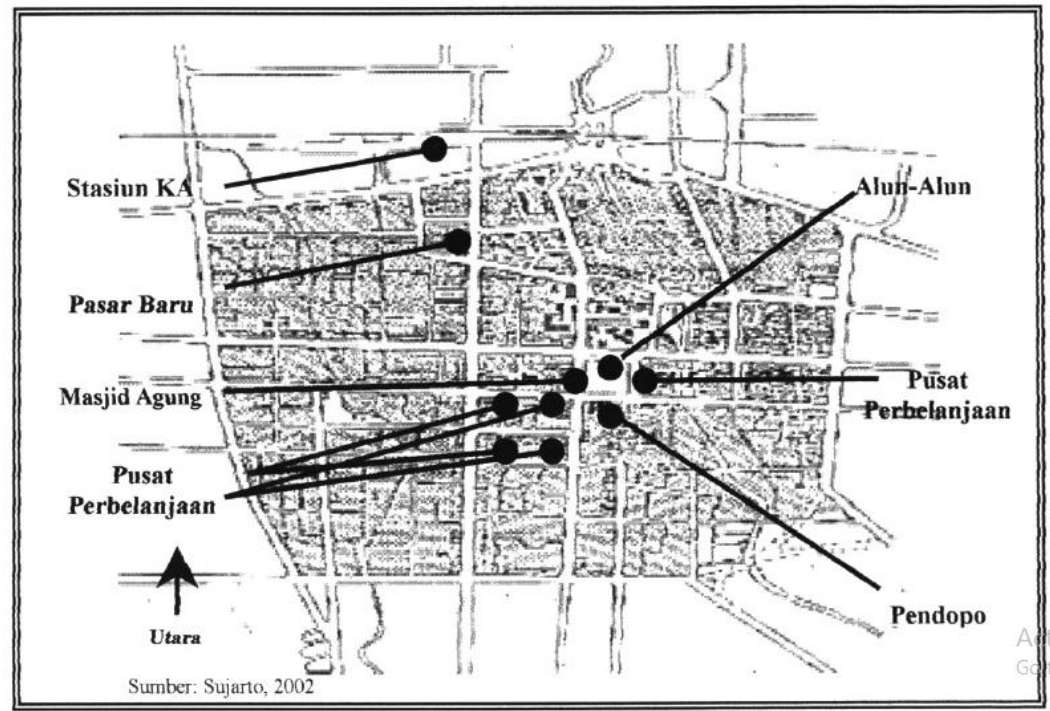

Figure 3 Map of Bandung City in the 2000s

Source: Sujarto (2002)

The map in figure 3 shows that MRB conditions in the early 21st century are already surrounded by shopping centers. This allows Muslims who visit the mosque, at the same time be able to carry out economic activities around the mosque environment. Several points of shopping centers are close to $\mathrm{MRB}$, this forms connectivity or spatial relations that lead to the formation of capital space.

In the Bandung City Regional Spatial Plan (RTRW) 2011-2031, MRB is located at the service center of the square and is placed as an economic strategic area (see figure 4). This proves that MRB has spatial connectivity that is interconnected with other spaces, including shopping centers, which are strategic economic areas in the RTRW for Bandung City 2011-2031. Seen from this point of view, the state makes use of the space it controls as a driving force for economic sustainability, more precisely capitalism. The placement of a strategic economic area by local governments in MRB and its surroundings cannot be separated from the many business spaces that exist there. Implicitly, the state is also involved in building capital space in strategic economic areas. This proves that as Gramsci wrote, the state contributes and determines something as it wishes (Gramsci, 1971). The determination of the strategic economic area aims to show that there is state power in that space. 


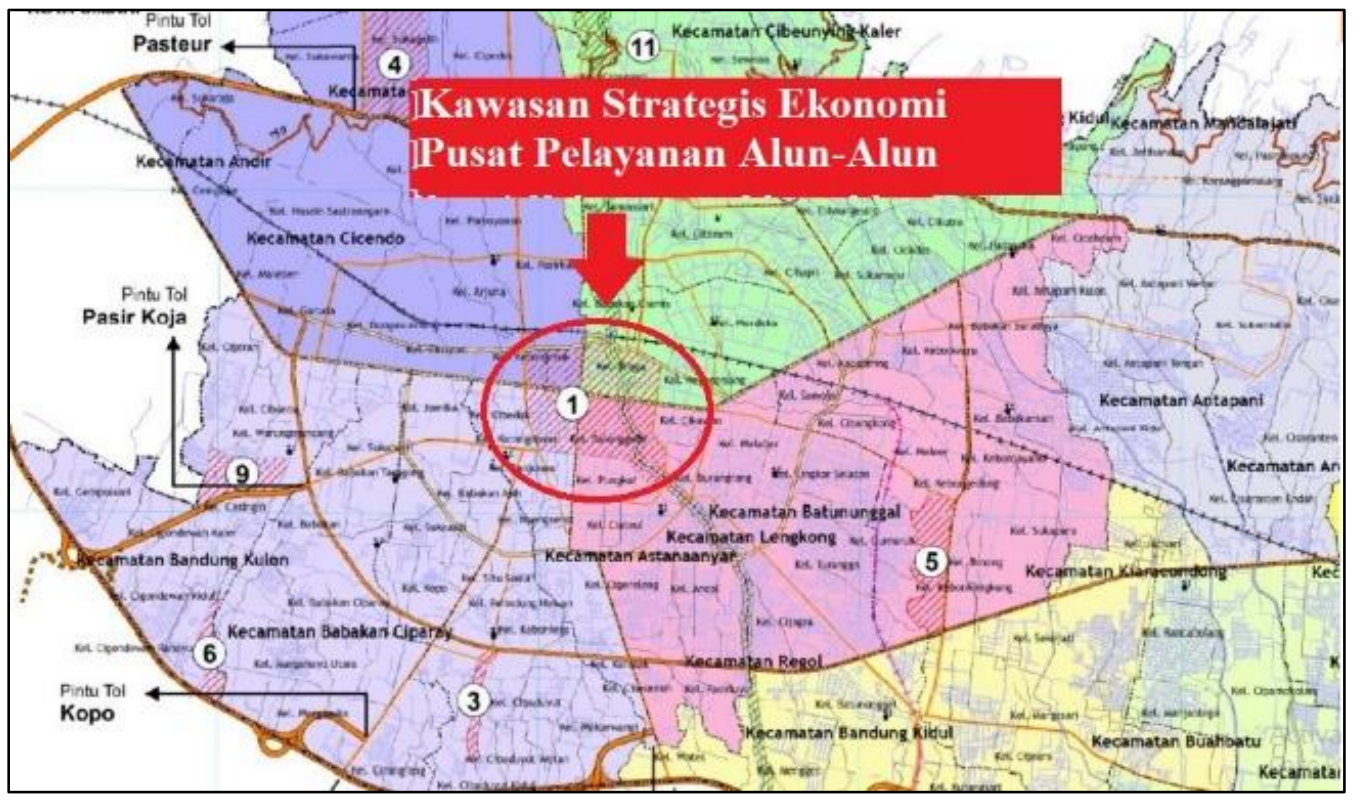

Figure 4 RTRW for Bandung City 2011-2031 (Map of the Strategic Economic Area of the Square Service Center) Source: RTRW for Bandung City 2011-2031

In addition to regulations from local governments that make MRB a strategic economic area, there is also an important relationship between MRB organizers and the West Java Provincial Government. On January 30, 2020, a meeting was held between MRB organizers and the Deputy Governor of West Java, Uu Ruzhanul, to discuss the condition of MRB and plans for renovating the mosque. According to the Deputy Governor of West Java, MRB renovation is important because a mosque is a historical place, and many people visit it at home and abroad (DKM Masjid Raya Bandung, 2020a). This overhaul plan aims to attract more public interest which will also have an impact on economic development in the city center.

In building MRB connectivity and economic spaces, it is strengthened by the existence of a close relationship between the West Java Provincial Government and MRB organizers as the implementer of local government regulations. As reported in the official website of MRB (DKM Masjid Raya Bandung, 2020b), when the inauguration of MRB management for the 2018-2021 period, the administrators was immediately prepared to carry out the West Java Provincial Government's vision, namely "The Realisation of West Java's Inner Born Champion with Innovation and Collaboration". This vision is translated into five missions, and among them are to accelerate regional development and connectivity as well as the economic competitiveness of a prosperous ummah. Given the relationship between West Java Provincial Government regulations and MRB organizers, it can be assumed that MRB is not only used as a place of worship but has other functions, one of which is an economic function and regional connectivity.

The regional connectivity is formed because the distance between MRB and the shopping center is close and can be reached only on foot. The spatial condition of MRB is surrounded by shopping places whose buildings are close together, so the activities of the people at the mosque are interconnected with activities in shopping centers.

The relationship between MRB and capital space can be seen from the placement or formation of buildings that are deliberately directed at strengthening economic distribution in the spatial landscape. The parking lot in the basement was built to make it easier for people to store their vehicles and directly head up to the MRB plaza (figure 5). Not only did it make it easier for people to go to MRB, but the traders were also deliberately placed under the stairs leading to the basement so that visitors who wanted to return to pick up their vehicles had to face the traders first. 


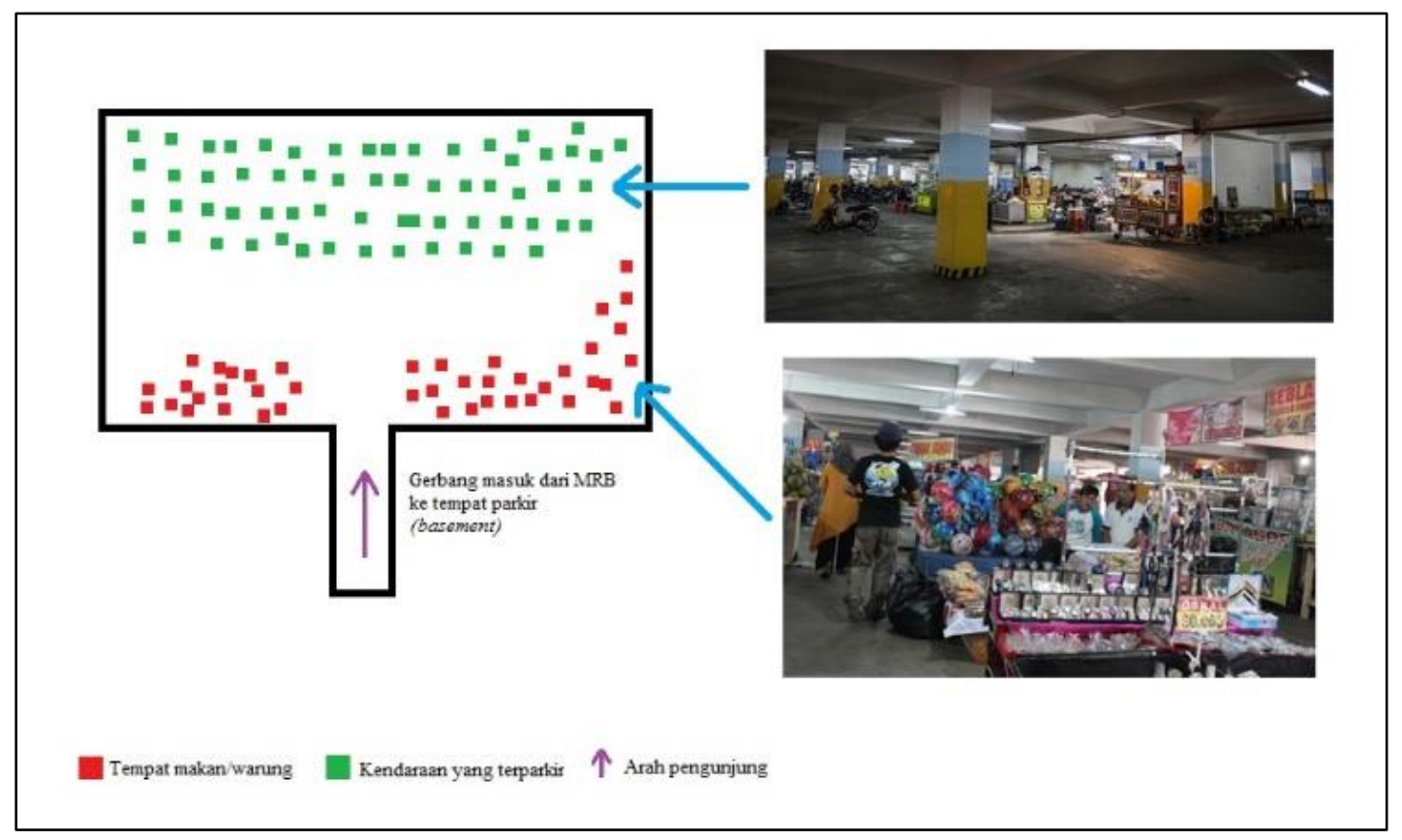

Figure 5 Parking lots and stalls in Basement Square

Source: Personal Documentation, 2020

When visitors pass through space, their bodies are required to accept all symptoms that appear in the parking lot. For the visitors who choose to stop by the traders first, it can be assumed that they have been called by the subject (in this case the merchant) ideologically. As Althusser has stated, each subject has an ideology and always carries out an interpellation process (Althusser, 2014, p. 236). Interpellation is a calling from one subject to another, or it can be called ideologisation via subject. In this context, the traders have succeeded in attracting visitors who are going to MRB to stop by and buy their wares. Visitors' bodies feel called because they see and smell food that suits their tastes. On the other hand, traders actively peddle their wares to visitors who go back and forth in the space, including visitors who have the aim to go to MRB. Visitors who have the same ideological frequency will carry out the buying and selling process in the space. The visitor bodies are thus conditioned according to the position of the space they occupy.

The traders in the basement initially traded in MRB, such as in the mosque yard. There is a regulation from the mosque that does not allow traders to enter the mosque area resulting in them being placed in the basement. This rule has been enforced since the restoration of the mosque and plaza, the goal is to make the mosque better organised. According to officers on guard around the mosque area, initially, the traders could freely use the mosque area as a place to sell. Now the traders are placed in the basement so that MRB visitors can shop and do not disturb the cleanliness and comfort of MRB.

MRB officers function as supervisors of visitors and traders. They will reprimand anyone who violates the rules, such as selling in the mosque area or visitors littering. These officers function to supervise the space so that it is used properly. In Foucault's perspective (Foucault, 1979), the officer becomes a panopticon who oversees the relationship between visitors, traders, and space used according to what has been arranged.

Other spatial relations can be seen from the absence of a parapet to the south of MRB (figure 6). The spatial difference between MRB and shopping centers is only characterised by the terrace or courtyard of the mosque. This spatial condition makes MRB a space connected to shopping centers such as Plaza Parahyangan, Yogya, Dunkin 'Donuts, and other spaces. The mobility of visitors to the shopping center is facilitated by the absence of the parapet. The visitors only need to leave that direction, then they will be faced with various places that provide their shopping needs. 


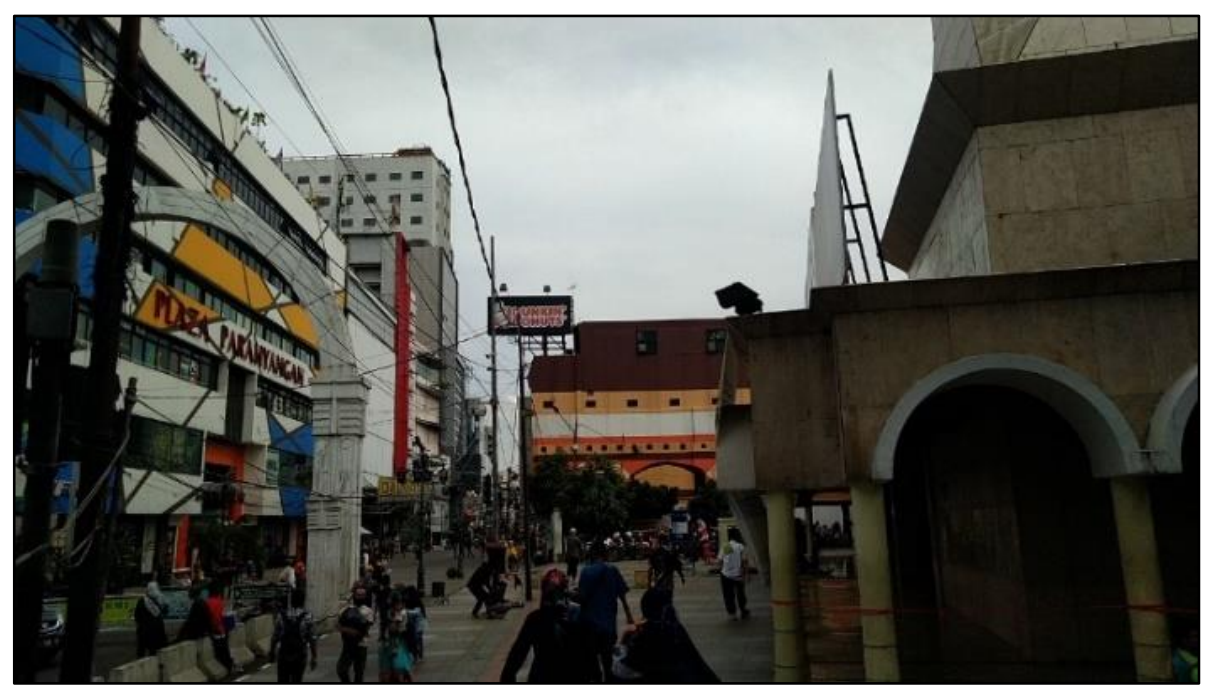

Figure 6 South MRB

Source: Personal Documentation, 2020

The image shows that the mosque can be seen as a plaza of a shopping center. Spatial practices that work in shopping centers also use mosque space so that these practices continue. The layout of the MRB space and the shopping center allows the spatial practice between the two to synergise. Shopping centers that do not have a yard because the building reaches the side of the road, is greatly helped by the large courtyard of the mosque as a medium for shopping center visitors to rest before and after shopping, or want to shop from one place to another.

To the north of MRB, there are BRI and Mandiri banks which easily facilitate the economic process around MRB. To the south of MRB, there are also BRI banks and ATMs. The south and north directions, which are the locations of the centers of economic activity, are made easier by the presence of banks and ATMs. Banks and ATMs are supporting media for visitors in the formation of capital space.

The mobility of people to shop around MRB is not only by providing shopping space but with all the media so that shopping can still be done in that spatial relationship. The formation of capital space in MRB and its relationship with the surrounding space is made easier by the presence of the bus stop to the north of MRB (figure 7). People getting off the bus at the bus stop can easily enter MRB via the north gate. The existence of a bus stop to the north of MRB has an impact on the relationship between the mosque and the shopping places around it. Economically, buses are transportation that is affordable to almost all people.

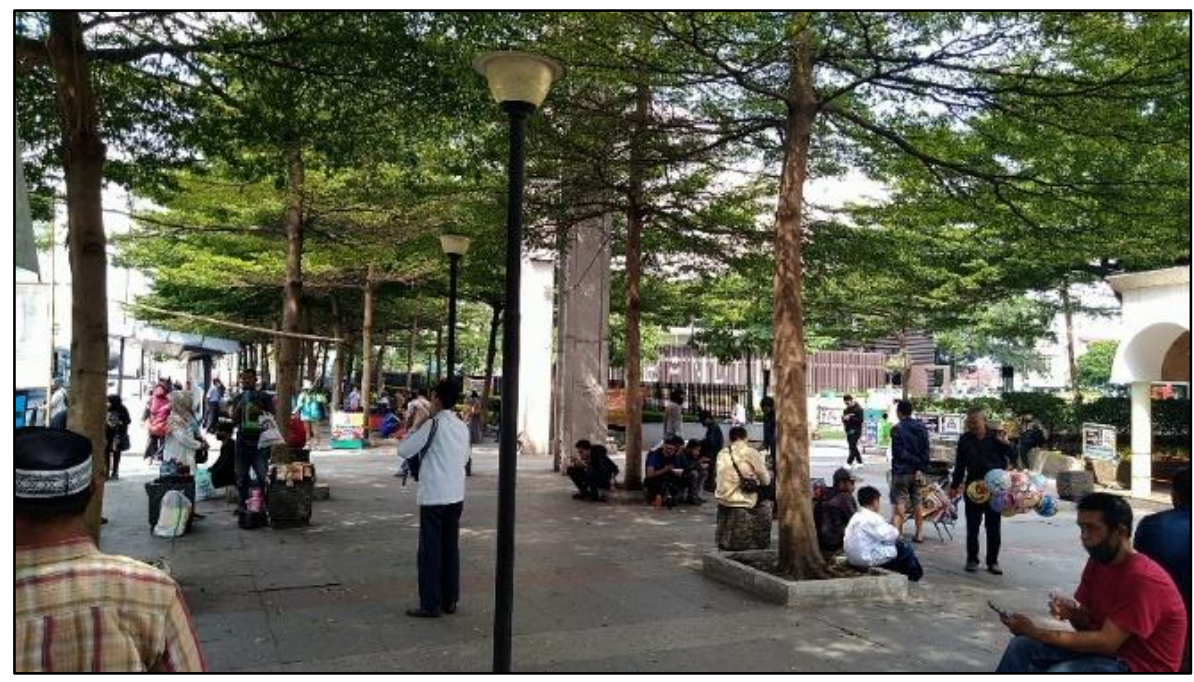

Figure 7 Bus Stop in the North MRB

Source: Personal Documentation, 2020 
The determination of MRB and its surroundings as a strategic economic area by the West Java Provincial Government is synergised by placing the bus stop to the north of MRB. The photo above shows that the spatial relationship between MRB and the bus stop is close together. Irfan (Personal Communication, February 10, 2020), whose house is located in Buah Batu, got to MRB by bus which then stopped just north of MRB. He deliberately went to MRB to visit the shopping center around the mosque and to perform Friday prayers in the mosque. This proves that the development of capital space in shopping centers around MRB is supported by the relationship between MRB and public transportation which is in an adjacent space layout.

Space connectivity in building capital space can also be seen next to the south gate. The south gate makes it easier for visitors to go to MRB toilets so that visitors can use MRB facilities while they shop at the shopping centers. For example, Fathan (Personal Communication, February 16, 2020), used the MRB toilet when he was shopping at the Parahyangan Plaza through the south gate of the mosque. The reason for using the MRB toilet is that there are no public toilets available in these shopping areas. So he chose to go to MRB to just pee and go back to shopping. Judging from this case, MRB is then used as a space for visitors so that they can continue their buying and selling activities in shopping centers. In this context, MRB is not used as a place of worship but rather is positioned as a secondary space for sustainability in shopping centers.

The most congested shopping spots are to the south MRB (figure 8), it seems that the gates are designed in such a way as to make it easier for people to enter the mosque. When exiting the gate, people are immediately confronted with shopping places. Various shopping places according to economy class are there. Starting from food vendors to toys sold on the roadside. Of course, these traders are associated with the lower class because the prices of their products are cheap. The space they occupy is also not a private space or space that requires large costs to occupy it. The spaces associated with the upper-middle class are shopping places with large, luxurious, and exclusive buildings. The price that must be paid by visitors to get or buy goods that have been provided in this space is different from the space occupied by street vendors.

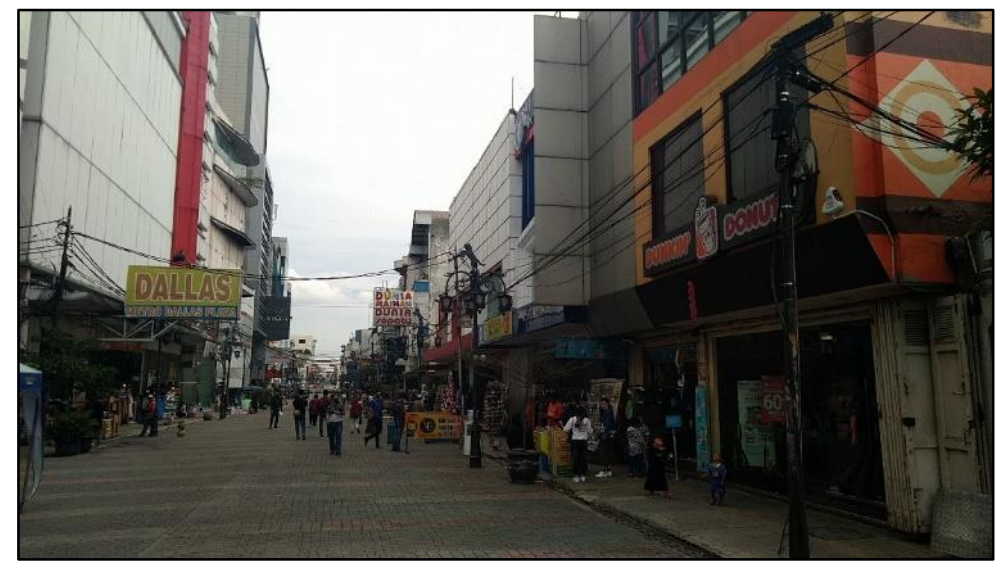

Figure 8 Shopping Centers in the South of MRB

Source: Personal Documentation, 2020

The shopping center south of MRB consists of several marketable segments. The shopping places that are present there are also various, starting from the plaza with large buildings to street vendors. There are at least three large plazas or shopping malls to the south of MRB: Parahyangan Plaza, Metro Dallas Plaza, and The Kings. Apart from the segment of food containers associated with a particular class in the previous review, other commodity places are also attached to a class system. For example, the clothes and accessories sellers on the side of the road are in a different class from the clothes sellers at the plaza or mall. In other words, the production of capital space is class production in shopping centers, because MRB visitors will be exposed to spaces associated with different classes.

According to Habermas, the public sphere should form a society that can communicate equally capable of creating communication conditions that allow citizens to carry public opinion (Habermas, 
Lennox, \& Lennox, 1964). This public opinion allows citizens to control the state and the market because the public sphere is separate from the state and the market. In the context of MRB, this public space is used as a space to build and strengthen capital space. Instead of MRB as a public space capable of producing public opinion and controlling the market, MRB is an amplifier for the formation of social class. The mosque is thus a secondary space or support for the continuity of production, distribution, circulation, and consumption around it. I will explain how this class is formed through daily practices that arise in MRB in the next sub-chapter.

In this subchapter, the relationship between MRB and shopping centers has been described by tracing its historical relationships. As previously described, MRB has undergone various spatial changes. MRB is a historical space, the space does not just exist but is transformed according to changes in its own space. Changes in MRB continue to lead to strengthening its relationship with other spaces in producing capital. The production of capital space is following Lefebvre's theory which sees the periodisation of space moving towards the formation of capital. MRB, which was previously interpreted as a sacred space, has changed because the mode of production that develops around it has further strengthened capitalism. MRB is currently a secondary space for the sustainability of economic activities in shopping centers. The use of MRB by people is not only for worship but as a supportive space for the visitor's body to carry out economic transactions in shopping centers. Its relation with other spaces makes it easier for people to access MRB while doing its relationship with capital space. The layout of the room is arranged in such a way that the visitor's body is directed at the capital.

\section{The intervention of Capital Space on practices of everyday life in MRB}

In this second sub-chapter, the discussion focuses more on spatial practices or practices of everyday life that are intervened by capital space. Seeing the production of space, it is necessary to also review the various activities or practices that arise in that space - in this case, is MRB - because as written by Lefebvre, the production of space includes daily practices that refer to all activities or social relations that work in a space' (Lefebvre, 1971).

Practices of everyday life, especially in terms of economy and the formation of capital space that exist in MRB today, are different from before. In the early 1950s, for example, daily practices related to shopping in MRB were the activities of traders around MRB. In that year, the traders were still limited, there were only food vendors, who were in front of the mosque and not as many as currently as has been reviewed in the previous sub-chapter.

The economic space that was formed in MRB and its surroundings in ancient times can be seen as a representation of the economic class which incidentally is the lower class. This can be seen based on the daily practice and production of MRB space which at that time was not directed as a commodity space as Kunto wrote, MRB was previously used for deliberation and was symbolised as a legislative (Kunto, 1996, p. 230). In contrast, if space is made for the upper class or the bourgeoisie, the production of this space will be directed as a commodity, money producer, financial market, cultural consumption, or urban development (Low, 2017, p. 38).

If you look at the daily practices that are currently emerging in MRB, MRB is used as a multifunctional space. In general, MRB is currently the same as before, which is still interpreted as a place of worship for Muslims. Like the usual mosques, MRB often holds recitations, distributes necessities, and performs congregational prayers. MRB is intended as a space for religious activities, but daily practices that emerge in MRB are not only seen from the realm of worship. There are also other activities outside of religion, including those related to daily practices that are intervened by capital space. I will describe the interventions of capital space in daily practices that focus on four actors: visitors, traders, workers, and religious communities.

The shopping centers around the mosque make daily practices that emerge in MRB correlate with the shopping centers. The formation of the capital space between the mosque and the surrounding spaces, including the shopping center, can be seen from the daily practices of visitors that occur between the relations of these spaces. The first thing I will explain is the daily practice of MRB visitors 
from the data that has been obtained, to prove that there is an intervention from capital space on the daily practices of visitors.

There are various daily practices of visitors in using shopping centers and MRB as interconnected spaces with their daily practices. Visitors who are shopping at shopping centers deliberately come to MRB just to charge their cellphones or take a ride to the toilet. Shopping places on the roadside or large plazas do not provide a place to charge visitors' cellphones. Shopping spaces that provide a place to charge cellphones are only places to eat that are associated with the upper-middle class such as Dunkin 'Donuts or KFC, while malls do not. For example, Hilman (Personal Communication, February 14, 2020) deliberately went to MRB to charge his cellphone battery after he shopped at Plaza Parahyangan. For him, the cellphone has become an important tool as a medium of communication, so before he continued to go around the shopping center, he first went to MRB to charge his cellphone while resting.

From the narrative above, it can be seen that MRB provides facilities that are not available in shopping centers. Visitors who do not have the facilities to meet their own needs choose to go to MRB, the electricity facilities in MRB can be accessed for free by visitors. The electricity is not reserved for visitors who want to charge their cellphones, but visitors are often seen using it for this purpose. Viewed from the perspective of space production, Hilman (Personal Communication, February 14, 2020) uses MRB as a perceived space to charge a cellphone battery. By using cell phones, MRB visitors can take pictures of their groceries or display them on social media.

As space, MRB is conceptualised (conceived space) as a place of worship, but because their daily practice is not only related to worship, visitors re-perceive MRB space according to their daily practices. Other facilities that are not provided by shopping centers are toilets. In large shopping areas such as malls, toilets are provided, but not all shopping places provide toilets for visitors, especially if visitors shop at street vendors. MRB provides toilets free of charge, although most visitors who enter the toilets put money in the charity box voluntarily. The existence of toilets that can be used in general creates a tighter relationship between daily practices in shopping centers and MRB. For example, Arif (Personal Communication, February 14, 2020) and his family went to MRB to urinate after going around the shopping center. Arif even brought his groceries into MRB.

Arif (Personal Communication, February 14, 2020) shopped at a shopping place that didn't have a toilet. If we look at this case, people who go to MRB toilets just to urinate or defecate determine the class space. People who prefer to shop in places where there are no toilets are usually the spaces associated with the lower middle class. That way, shopping center visitors who go to MRB toilets between shopping activities are those who come from the lower middle class.

Not all shopping places provide facilities for the needs of the visitor's body so that they can carry out economic activities in that place. The spatial relationship between MRB and the shopping center is close, allowing visitors to move to find every need for their bodies. Shopping centers provide items that visitors want to buy, while MRB provides necessities that are not found in some shopping centers.

There are facilities in MRB that are used by shopping center visitors, actually not specific to complement shopping facilities, although spatially the two spaces are related to each other. MRB applies rules for its visitors not to use the mosque to lie down. In other words, although MRB is often used as a secondary space for the continuation of buying and selling activities in shopping centers such as rest areas - some restrictions need to be obeyed by every visitor. Borrowing Certeau's term (Certeau, 2001, pp. 130-131), in MRB there are daily practices that show strategies and tactics. The strategy shows the rules that apply in MRB, which is marked by the installation of a signboard and officers who always control the mosque. Meanwhile, tactics were practiced by MRB visitors who did activities that violated MRB rules, such as resting and sleeping in the MRB area as shown in figure 9. 


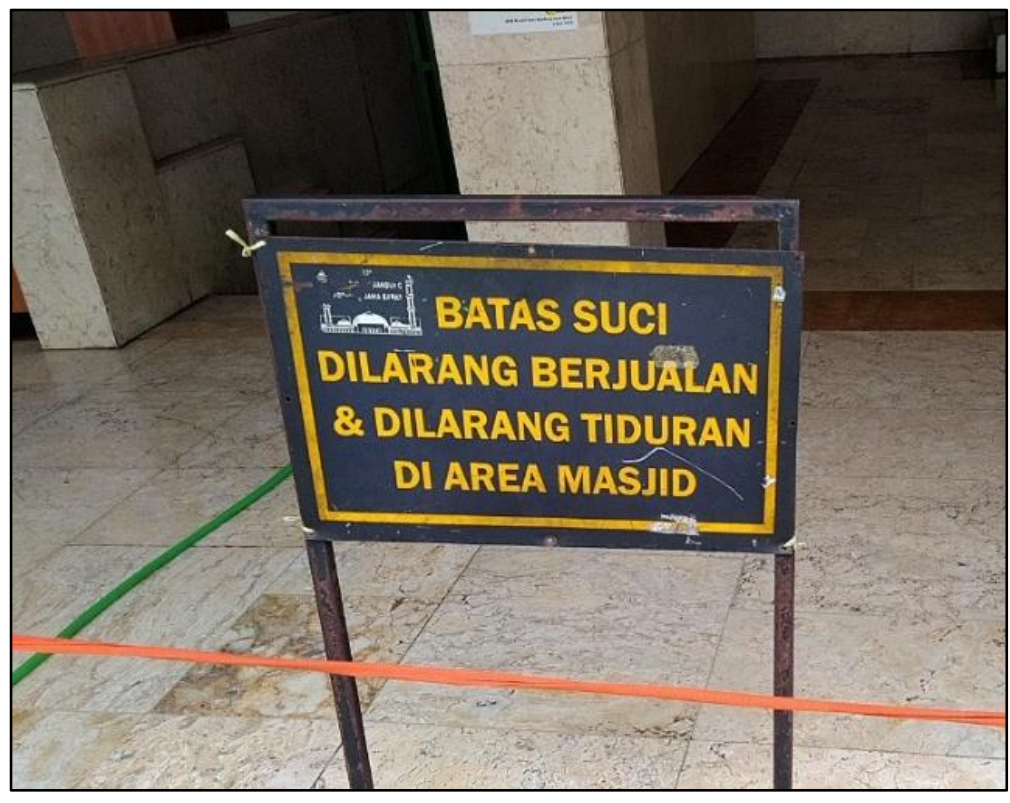

Figure 9 Prohibition Board for MRB Visitors

Source: Personal Documentation, 2020

After I observed in the mosque area, it turned out that many were resting while lying down, either inside or outside the mosque. Among the visitors who come to MRB to sleep are visitors from shopping centers. For example, BS (Personal Communication, February 14, 2020) rested at the mosque after going around the shopping center south of MRB.

The daily or spatial practices carried out by BS (Personal Communication, February 14, 2020) can be seen as tactics because they collide with the strategies adopted by MRB. Although not all visitors carry out daily practices that violate the rules applied by MRB - in Certeau's term (2001) it is called a strategy. Some of the visitors were uncomfortable with the tactics that appeared in MRB. For example, Alwan (Personal Communication, February 14, 2020) argues that visitors who use such a mosque are very disturbing, especially if those who are lying down and sitting along the aisles and entrances block the entrance to the mosque. In Certeau's perspective, there are always daily practices that support the prevailing rules (strategies). In this case, although Alwan (Personal Communication, February 14, 2020) and BS (Personal Communication, February 14, 2020) are both visitors to shopping centers and MRB, one is in a position as someone who carries out daily practices that support strategy, while the other is against strategy or is in a tactical position.

The daily practices shown by BS (Personal Communication, February 14, 2020) as part of the tactic can occur because his activities at the shopping center require his body to rest to recover his strength. As seen in this case, the capital space formed in the shopping center also intervenes in the daily practices of visitors, their bodies then choose MRB as part of their restroom after they carry out activities in the shopping center. It is assumed that the daily practice of working using the relationship between MRB and shopping centers is because the space is adequate to create this practice.

Addressing other daily practices outside of worship allows MRB space not to be used only normatively. As previously explained, the mosque is one of the spaces that is used multi-functionally, including in an economic context. People who visit MRB sometimes have other intentions other than praying. Of the goals of these visitors, they came to the mosque as a means of traveling. Not only enjoying tours in the mosque area, but they and their families can also enliven activities in shopping centers around the mosque. Because the objective is tourism, they also automatically do not just visit MRB but also support economic activities in the area, such as buying children's toys or food outside the mosque area.

In the north, which is adjacent to the square stop, visitors are seen busy buying food there, some are buying grilled sticky rice, various kinds of drinks, meatballs, and other foods. They then eat these snacks on the terrace of the mosque. Seen from this context, there is a spatial practice that is related to 
the practice that works in MRB and the shopping place - in this case, the traders. Activities, when visitors walk to traders and then carry out economic transactions, is a spatial practice that works in a shopping place, but when the visitor sits on the mosque terrace and eats his food it is a spatial practice in the MRB room.

The activities of visitors at MRB related to daily economic practices can not only be observed in the field directly but can also be seen from the many testimonies of visitors on Google Maps. From these testimonies, some use MRB as a place to rest, take photos, and travel or play while animating the economic activities around them.

From the comments above, it is illustrated how the spatial conditions and perceptions of the visitors about MRB. The presence of traders around MRB is not always positively perceived by visitors. Among MRB visitors there were comments that it made the mosque look shabby. This proves that although there are daily practices of visitors who use two spaces - MRB and the shopping centers and the two spaces are interconnected, their perceptions of spatial relations and practices that emerge in these relations are interpreted differently.

Apart from being seen from the daily practices of MRB visitors and shopping centers, the daily practices of traders or sellers also need to be observed as part of the formation of capital space that intervenes in their daily practices. The availability of MRB space is considered beneficial for traders, because among the visitors who come to their shop are MRB visitors. MRB thus becomes a space that is perceived by traders in providing potential customers. An example that can be seen in this context is for example when the traders in the basement of the square feel benefited or their merchandise will be more in demand when Friday arrives. This is because people who want to or after performing Friday prayers at MRB often buy snacks from traders. After prayer, they usually take a break at food stalls before returning to their activities. Various food vendors sell in the place, and they sell various types of food, from heavy food, snacks, to various drinks. Of course, visitors can choose the food they want based on their wishes or according to the money they have. On the other hand, traders also feel benefited because more visitors come to MRB than on usual days. Usually, the MRB room is fully occupied by people who are performing Friday prayers starting from the top level to the part below.

Some visitors who leave the mosque after Friday prayers often stop by the food vendors who are outside the MRB area. One of the mosque visitors who finished performing Friday prayers, for example, bought grilled sticky rice to the north of MRB (see figure 10). When I joined the activities of the visitors after Friday prayers I saw the visitors going to the food vendor area and ordering food there. This proves that the spatial practices carried out at MRB at that time (Friday prayers) affected traders.

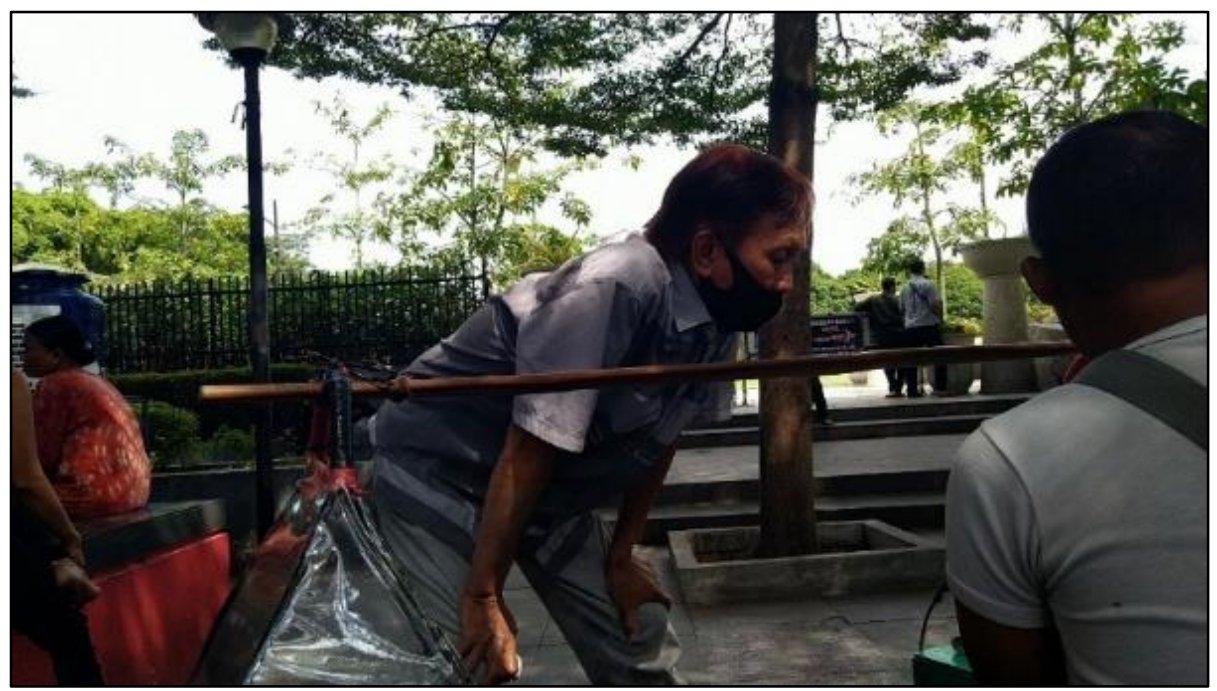

Figure 10 MRB Visitors After Friday Prayers

Source: Personal Documentation, 2020 
From the results of interviews with traders, it is known that they feel the benefit when it is Friday because space will be fuller than usual days considering the distance between traders and MRB is very close. A grilled sticky rice trader to the north of MRB named Mahmud, always prepares at his stall before Friday prayers are over because according to him MRB visitors will pass through a room filled with traders (Mahmud, Personal Communication, June 28, 2020). Seen in this context, the practice of worship which is carried out in the MRB room is in synergy with the formation of a capital space outside the MRB room. This synergy is built through spatial or daily practices that connect two different spaces.

Another relationship between religious activities and the economy that can be seen from the daily practices of visitors and MRB is when the month of Ramadan arrives. In the month of Ramadan, merchandise around MRB is more in demand than other months. Many visitors come to MRB to play while waiting for the breaking time. According to Sukman (Personal Communication, June 28, 2020), a Batagor trader to the north of MRB, visitors choose MRB as a place to hang out: waiting for the time to break their fast. This Ngabuburit activity makes space more crowded in shopping centers or MRB, including benefiting traders because there are more visitors than in the usual month. Visitors who choose to buy food to break the fast, then some of them use MRB yard as a place to break the fast.

The mosque also provides takjil (snacks for breaking the fast) for visitors. As reported by Republika (Madani, 2019), in 2019 MRB will provide 1,000-2,000 takjil every day. This takjil is intended for all MRB visitors. Iqbal (Personal Communication, February 14, 2020), once took takjil at the mosque to break his fast after going around in a shopping center. The activity of Iqbal shows that there is a relationship between spatial practices in MRB and shopping centers during the month of Ramadan. There was no specificity for the distribution of takjil at that time for each MRB visitor (Iqbal, Personal Communication, February 14, 2020). In the context of Ramadan, the visitor's body is filled with two different but interconnected spaces. The need to consume goods for Eid al-Fitr is met through shopping centers, while the needs for eating and breaking the fast are found at MRB. On the other hand, traders also feel benefited by the increase in the number of MRB visitors when Ramadan arrives which affects their merchandise or shop.

Daily practices that show that there is a synergy between the practice of worship and the production of capital space around MRB can be seen from the behavior of people who are members of religious studies in MRB. Amalia (Personal Communication, February 14, 2020), attended several public lecture studies held by MRB. After completing the recitation, according to him the recitation women often chat first and buy food provided by the traders around MRB such as meatballs, grilled sticky rice, or other foods. According to him, the number of participants in religious studies scheduled for each day from morning to evening by MRB was not too many, perhaps tens of people. According to Muhtar Gandaatmaja as the chairman of MRB organizers, Muhtar encouraged forty-three majelis taklim (religious study gathering) to prosper MRB by filling Islamic activities or activities in mosques (Cécép, 2020). If you look at the large number of majelis taklim in MRB, and every day they always carry out activities according to their respective schedules, then it is not only the practice of worship that works in it but also has an impact on the activities around it, including strengthening economic processes.

This relationship between the practice of worship and economic growth differs from that of Protestants, as described by Weber. If Protestants are indoctrinated with religious teachings to achieve the material wealth of their group, this is different from the case that surfaced in MRB. There is no specific study material about the pursuit of wealth (Calvinism) - as happened in Protestantism -in the $\mathrm{MRB}$ congregation. Economic growth and its relationship with religion in the context of MRB are seen more from the interconnected daily practices of MRB and shopping places. In simple terms, religious practices in MRB attract a lot of visitors and have implications for economic growth around the space (Weber, 1958).

Daily practices related to MRB and shopping centers can also be seen from the workers. The workers in question are workers located around MRB. Some of these workers use MRB as a restroom so that the workforce can continue to carry out production or buying and selling around MRB. In other 
words, MRB is positioned as a resting room for workers around MRB, but MRB space is outside the corporate structure, shopping centers, and other business spaces. If you look outside and inside the mosque, in MRB many people are resting, such as lying or sleeping. Among the people who do this are workers who work around MRB. Usually, they take a break from between work, Ramdan (Personal Communication, February 16, 2020), a satpol PP (Satuan Polisi Pamong Praja - Regional Government apparatus in maintaining public order) who is on duty around the square, sometimes visits MRB to rest and perform prayers at MRB. Satpol PP is on duty in the field so that there is no room for them to rest, sometimes they can be seen sitting on available chairs on the side of the road. Some of them are guarding the shopping center at Jalan Dalem Kaum and some at MRB.

Satpol PP plays an important role in maintaining the situation of the space, be it in a shopping center or MRB. They usually observe the movements of visitors and traders who carry out their daily practices there. Borrowing Foucault's term (1979), this satpol PP can be seen as a panopticon that monitors the movements of visitors to comply with applicable regulations. The presence of this satpol PP makes visitors in shopping centers comfortable for their activities because they feel protected from crimes such as pickpockets but also under surveillance. Satpol PP's task, which looks like a panopticon, strengthens the daily practices of visitors who use MRB and shopping centers. The visitors feel comfortable to shop because there is a supervisor from the satpol $P P$, so that in that room one can process economic transactions safely. On the other hand, the panopticon which in this case is represented by satpol PP will take action against the traders who sell randomly in the mosque area. The presence of Satpol PP also contributes to building capital space relations between MRB and shopping centers, because they control the use of space.

Friday is the most appropriate day to see how workers around MRB come to the mosque to come Friday prayers and fill their rest time. Some workers from offices or malls go to MRB for Friday prayers then after that, they sometimes buy the food that is in MRB before they return to their workplaces. From the results of the observations made, I saw workers wearing various work uniforms entering the mosque. They perform Friday prayers, rest, and revive economic activities at the vendors' premises by buying their food.

The traders around the mosque often use MRB as a place to rest. Patmi (Personal Communication, February 14, 2020), and her husband, who both sell meatballs in the basement, take turns looking after their wares. When the time for prayer arrives, they take turns to MRB to pray. According to Patmi (Personal Communication, February 14, 2020), they also took turns resting. Her husband often took a nap in the mosque first. These resting people can usually be found in the area inside the mosque at the earliest. This proves that MRB is also used as a break room so that companies, small traders, and shopping centers can carry out their economic processes.

Althusser wrote that there are three ways to restore the strength of the workforce, namely by wages, teaching skills to the worker, and institutions controlling workers (Althusser, 2014, p. 234), this is different from the case in MRB. In this context, MRB as a place of worship located in the city center and associated with workplaces becomes an important part for workers as a place to rest to restore their workforce. In other words, although MRB is not a space that specifically carries out its capital production, MRB can be a supportive space for workers to carry out economic processes in the workplace-such as companies, shopping centers, and traders-because the place of worship can reproduce or restore labour force.

In some cases, MRB is also used as a space to process transactions for traders and/or workers around the mosque. Fikri (Personal Communication, February 10, 2020), who comes from Pameungpeuk, Bandung Regency, as a book trader, uses MRB as a place to make Cash on Delivery (COD) transactions, and meet his book customers from Facebook. In this context, MRB is not only a profitable space for workers and traders around MRB, but also for workers who are located far from MRB.

Previously, it has been discussed about the daily practices of various actors who have emerged in MRB and shopping centers, these practices will then form a representational space. This representation space can be seen from the visitors' conception of MRB. In other words, MRB, as is a space that is 
perceived by the people, presents there, especially those related to existing practices in shopping centers. People who visit MRB have their intentions and goals which are reflected in daily practice in the previous explanation. The representation space that will be seen in this context is the space that is perceived by people as being related to two spaces at once: MRB and shopping centers.

The consequence of the formation of capital space is that each shopping space around MRB is labeled or associated with its respective social class. On the other hand, in plain view, the mosque is seen as a space that is free from class divides, but the mosque is also an integral part of the formation of capital space around its area. The purpose of being free from class boundaries is when a mosque becomes a destination space for everyone from various classes, be it the poor, rich, laborers, and other professions can enter freely and carry out their activities in the mosque to perform worship or just rest. MRB and the square are completely open space for the community regardless of differences in economic class. In other words, MRB and the square have become public spaces. But it is precisely through this public space that the shopping centers around MRB have also strengthened.

In the context of MRB as a public space, the freedom that is presupposed by the theory of the public space towards market determination does not occur. This is because the public space -in this case, is $\mathrm{MRB}$-is surrounded by capital spaces. In the end, public space becomes a space used by the market for the performance of capital accumulation. The implication is that daily practices in urban space are not neutral. It is because of the effect of industrialisation on capitalist society (Lefebvre, 1991, p. 65). Finally, daily practice is programmed according to the needs of city regulation which has been fulfilled by industrialisation.

Amid this market intervention, MRB looks more like a plaza or shopping center, in other words, MRB is a supportive space or a secondary capital space for economic sustainability in the surrounding spaces. The main economic activity is not within MRB but MRB has an important role for economic continuity outside its space, for example as a place of rest for workers or traders, as well as other needs that have been reviewed in daily practices that link actors with MRB and shopping centers.

In Europe, the square or plaza is usually in front of a government building, palace yard, or where people gather. The square referred to here refers to the term square which means open air space, for example, such as Trafalgar Square (UK) or Plaza del Campo (Italy). The surrounding facilities include hotels, banks, department stores, and shopping centers. The plaza served as a place for commerce, court, politics, and transportation (Meilawati, 2019, p. 65). Judging from the general condition of the plaza in Europe, which is located in the city center and adjacent to shopping places, the square is used as an economic space. In contrast to MRB, because the square has become a mosque plaza, it is MRB that contributes to the perpetuation of economic activities in the vicinity. Economic activities or transactions are not within MRB spatial boundary but have a relationship with the existing space outside MRB.

This different spatial relationship has implications for emerging daily practices. In general, daily practices in European plazas are not related to issues of worship, especially Islam. In contrast to MRB, precisely by seeing MRB as a shopping center plaza, there are daily practices that are interconnected between issues of worship and the economy. As previously reviewed, for example, traders feel more profitable if it is Friday, because people who want to or after performing Friday prayers will buy their wares.

MRB, seen from the production of capital space, becomes the perceived space of the various actors involved between the two spaces: MRB and shopping centers. The visitors perceive MRB as a place of rest, a space to fulfill the need to go to the toilet or other activities that support visitors to continue the consumption process in shopping centers. For sellers or traders, the presence of MRB contributes to their sales, or in general effects increasing economic activity in urban areas. MRB also contributes to workers, whether in offices or not, who are around the mosque as a place to relieve stress at work by praying at the mosque or simply taking a break. For local governments, MRB can encourage the realisation of one of its visions to accelerate development and regional connectivity as well as prosperous economic competitiveness. 
Actors who carry out activities in MRB and shopping centers position MRB as their living space, economic life runs in shopping centers, but the presence of MRB also supports their daily practices in shopping centers. The existing spatial conditions make MRB a space that is connected to other spaces. The spatial connection can be seen from spatial practices that are articulate and require not only one space - in this context, MRB and shopping centers. Coupled with spatial practices as described earlier, it shows that MRB and others are connected to form capital space through regional connectivity.

In the previous section, I described the relationship between MRB and shopping centers in producing capital space. In this section, I described more emphasis on daily practices related to MRB and shopping centers. From the results of observations and interviews with visitors, traders, workers, and people who take part in religious studies at MRB, it can be concluded that they do their daily practices not only in MRB but also contribute to the economic development in the surrounding space.

\section{Conclusions}

From the above explanation, it can be concluded that MRB, which is located in the city center, is not only seen as a place of worship but more than that it is also a capital space. The formation of capital space implies that MRB contributes to the perpetuation of the economic process or consumerism in the shopping centers around it.

From various visible economic spatial practices, MRB is used as a capital space so that the circulation and consumption process continues in the center of Bandung. Although there is no production process for commodities, labor, and the means of production that characterise capitalism, MRB is a secondary capital space. On the other hand, the position of MRB as a public space can direct people to build their respective economic classes through their relationship with the shopping centers around MRB. The public space, which in theory is not part of the market, as Habermas commented on, in this context, the public space is the perpetrator of the market itself.

MRB is also a space to reproduce the labour power. The workers or traders who carry out their activities around MRB position MRB as a rest space or workforce recovery space so that their work processes can continue to run smoothly. That way, the process of restoring the labour power is not only through wages, teaching skills to the worker, and through institutional rules as written by Louis Althusser, but in this context, the mosque can also be a tool for labour - power.

\section{References}

Afriandi, M. A. (2003). Konformitas Kebijakan Pemerintah Kota Bandung Terhadap Karakteristik Spasial Pedagang Kaki Lima. Yogyakarta: Universitas Gadja Mada.

Althusser, L. (2014). On the Reproduction of Capitalism: Ideology and Ideological. London: Verso.

Ashadi, A., \& Nur'aini, R. D. (2017). Fungsi Masjid Bersejarah Luar Batang, Jakarta Utara, dan Pengaruhnya Terhadap Pola Permukiman di Sekitarnya. NALARs Jurnal Arsitektur, 16(2), 169-178. https://doi.org/10.24853/nalars.16.2.169-178

Boer, R. (2015). Marxist Criticism of the Hebrew Bible. London: Bloomsbury.

Cécép, K. . (2020). Drs. K. H. Muhtar Gandaatmaja “Masjid Ulah Dipaké Sarana Politik!” Galura Waktu Sungsang, Badra 1956 Caka Sunda, Issue II, 8.

Certeau, M. de. (2001). Walking in the City. In S. During (Ed.), The Cultural Studies Reader. London \& New York: Routledge.

DKM Masjid Raya Bandung. (2020a). Pertemuan Pengurus DKM Masjid Raya Bandung dengan Wagub Jabar. Retrieved October 11, 2020, from Masjid Raya Bandung website: http://www.masjidraya.com/2020-0222/pertemuan-pengurus-dkm-masjid-raya-bandung-dengan-

DKM Masjid Raya Bandung. (2020b). Wakil Gubernur Jawa Barat Mengukuhkan Pengurus DKM Masjid Raya Bandung Provinsi Jawa Barat. Retrieved October 11, 2020, from Masjid Raya Bandung website: http://www.masjidraya.com/2018-10-16/wakil-gubernur-jawa-barat-mengukuhkan-pengurus-dkm

Falah, M., Yuniadi, A., \& Andyawardhina, R. (2019). Pergeseran Makna Filosofis Alun-alun Kota Bandung pada Abad XIX-Abad XIX. Patanjala: Jurnal Penelitian Sejarah Dan Budaya, 2(2), 203-218.

Foucault, M. (1979). Discipline and Punish. New York: Vintage Books.

Gazalba, S. (1994). Mesjid: Pusat Ibadat dan Kebudayaan Islam. Jakarta: Pustaka Al-Husna.

Ghulyan, H. (2019). Lefebvre's Production of Space in the Context of Turkey: A Comprehensive Literature 
Survey. SAGE Open, 9(3), 1-14. https://doi.org/10.1177/2158244019870537

Gramsci, A. (1971). Selections from the Prison Notebooks. New York: International Publishers.

Habermas, J., Lennox, S., \& Lennox, F. (1964). The public sphere: An encyclopedia article. New German Critique, No. 3, 3, 49-55.

Husain ibn Muhammad Al-Raghib Al-Asfahani. (2004). Mu'jam Mufradat Alfaz al-Qur'an. Beirut: Dar El-Koton Al-Ilmiyah.

Istiqamah, \& Herlily. (2018). Islamic Representation and Urban Space in Banda Aceh: Linking The Social and The Spatial. IOP Conference Series: Earth and Environmental Science, 124, 1-12.

Khan, H.-U. (1990). The Architecture of the Mosque, an Overview, and Design Direction. In S. Hayat (Ed.), Expressions of Islam in Buildings (pp. 109-127). Singapore: Concept Media/The Aga KhanAward for Architecture.

Kong, L. (1993). Ideological Hegemony and The Political Symbolism of Religious Buildings in Singapore. Environment Unci Planning D: Society and Spoeo, 11(1), 23-45.

Kunto, H. (1984). Wajah Bandoeng Tempoe Doeloe. Bandung: Granesia.

Kunto, H. (1986). Semerbak Bunga di Bandung Raya. Bandung: Granesia.

Kunto, H. (1996). Ramadhan di Priangan Tempo Doeloe. Bandung: Granesia.

Laclau, E., \& Moeffe, C. (1985). Hegemony and Socialist Strategy: Towards a Radical Democratic Politics. London: Verso.

Lefebvre, H. (1971). Everyday Life in the Modern World. Harmondsworth: Allen Lane.

Lefebvre, H. (1991). The Production of Space. Oxford: Blackwell Publishing.

Low, S. (2017). Spatializing Culture: The Ethnography of Space. London: Routledge.

Madani, M. A. (2019). Suasana Buka Puasa Bersama di Masjid Raya Bandung. Retrieved October 23, 2020, from Republika website: https://www.republika.co.id/berita/inpicture/nasional-inpicture/19/05/07/pr4z8t283suasana-buka-puasa-bersama-di-masjid-raya-bandung

Marwati, \& Sutriani. (2019). Integrasi Batas Suci Terhadap Tipologi Ruang Bangunan Masjid Modern di Makasar. Nature: National Academic Journal of Architecture, 6(1), 83-96. https://doi.org/10.24252/nature.v6i1a8

Mateo, M. P. (2019). The Mosque as an Educational Space: Muslim Women and Religious Authority in 21stCentury Spain. Religions, 10(222), 1-12. https://doi.org/10.3390/rel10030222

McAlister, E. (2005). Globalization and the Religious Production of Space. Journal for the Scientific Study of Religion, 44(3), 249-255. https://doi.org/https://doi.org/10.1111/j.1468-5906.2005.00283.x

Meilawati, L. (2019). Dokumentasi dan Inventarisasi Nilai-Nilai Filosofis Kebudayaan Sunda Kontemporer dalam Tata Ruang Daerah Alun-Alun di Depan Kabupaten/Kota. Sumedang.

Nyhagen, L. (2019). Mosques as Gendered Spaces: The Complexity of Women's Compliance with, And Resistance to, Dominant Gender Norms, And the Importance of Male Allies. Religions, 10(5), 1-15. https://doi.org/10.3390/rel10050321

Pawitro, U. (2015). Perancangan Kawasan Jalan Dalem Kaum dan Pajagalan Bandung Sebagai Bagian dari Kearifan Budaya Arsitektur Kota. Seminar Nasional Scan\#6: Finding The Fifth Element... After Water, Earth, Wind, and Fire" Local Wisdom and Cultural Sustainability", 122.

Putrie, Y. E., \& Maslucha, L. (2013). Seting Prilaku dan Teritorialitas Ruang Sebagai Perwujudan Adab di Masjid Gading Pesantren Kota Malang. Jurnal El-Harakah, 15(2), 185-198.

Ryan, M. (2010). Cultural Studies: A Practical Introduction. Chichester: Wiley-Blackwell.

Setiawan, R. A. (2017). Kawasan Religius dan Produksi Ruang di Lingkungan Masjid Pathok Negara Plosokuning Yogyakarta. Jurnal Religi, 13(1), 21-37. https://doi.org/10.14421/rejusta.2017.1301-02

Siswanti, N. (2016). Fungsi Masjid Sendang Duwur Sebagai Wujud Akulturasi Budaya. Jurnal SMaRT Studi Masyarakat Religi Dan Tradisi, 2(1), 143-154. https://doi.org/10.18784/smart.v2i2.382.g248

Sujarto, D. (2002). Peremajaan Kota. Bandung: Departemen Teknik Planologi ITB.

Weber, M. (1958). The Protestant Ethics and Spirit of Capitalism. New York: Charles Scribner's Sons.

(C) 2020 by the authors. Submitted for possible open access publication under the terms and conditions of the Creative Commons Attribution (CC BY SA) license (https://creativecommons.org/licenses/by-sa/3.0/). 